Flora of Protected Areas - 2:

\section{A NOTE ON THE ORCHID FLORA OF SITAMATA WILDLIFE SANCTUARY, RAJASTHAN}

\section{Satish Kumar Sharma}

Foundation for Ecological Security, 18, New Ahinsapuri, Fatehpura, Udaipur, Rajasthan 313001, India

Email: 'fes.udaipur@gmail.com

Orchids are mainly confined to three localities in Rajasthan i.e., Mount Abu Sanctuary in Sirohi District, Phulwari Sanctuary in Udaipur District and Sitamata Sanctuary in Udaipur and Chittorgarh districts. So far, orchid flora of two protected areas, namely, Mount Abu and Phulwari have been studied by Mehta (1979), and Sharma (2002, 2003). Except for one report (Sharma, 2001), nothing is known about orchid flora of Sitamata Wildlife Sanctuary, while it is one of the important sanctuaries of the state from rare biota point of view. Orchids, tuberous plants, climbers and lianas, bryophytes and pteridophytes are worthy of being sighted here.

It is believed that Devi Sita spent her days of exile in this forest, where the ashram of Rishi Valmiki was situated, hence the name for the sanctuary (Shekhawat, 2003). The sanctuary lies in the civil districts of Udaipur and Chittorgarh in southeastern part of Rajasthan at the confluence of Aravallis, Vindhyas and Malva Plateau. Tectona grandis with its associates form the dominant species of the sanctuary. Mixed deciduous to semi-evergreen patches of Mangifera indica, Buchanania lanzan, Hiptage benghalensis, Syzygium heyneanum etc. are confined along perennial streams. Sitamata Sanctuary is very rich in perennial network of streams. Canopy density near streams varies from 0.8 to 1.0. Many species like Leea macrophylla, L. edgeworthii, Smilax zeylanica, Peperomia pellucida, Ficus hispida, Carvia callosa, Sauromatum pedatum, Arisaema tortuosum, Colcocasia esculenta, Impatiens balsamima, Argyreia sericea, Euphorbia fusiforms, Flemingia bracteata, Selaginella repanda etc. are common ground flora.

Considering the aridity of the state, the orchid diversity in Sitamata is very rich. Huge sized rough-barked shady trees harbour epiphytic orchids on their stem and branches. Trees near Valmiki Ashram and along the way to Sitamata temple and
Jakham dam possess epiphytic orchids in abundance. Terrestrial orchids are common along the streams and valleys having good soil depth and thick cover of shady trees. One can find many terrestrial orchids from Bhagi Baori to Sitamata temple. Nervilia aragoana, a single-leaved orchid grows with Costus speciosus on the banks of Sitamata River. Thickets of Costus speciosus can be seen occasionally in Sitamata Sanctuary in riverine habitat, especially on the way to Sitamata temple.

Habenaria furcifera has not been reported earlier from any part of Rajasthan, hence it is a new report from the state. It is commonly seen in shady, cool localities of Sitamata during rainy season. It is a common orchid seen from Bhagi Baori to Valmiki Ashram and adjacent areas. Besides Sitamata, this species is quite common in many parts of Udaipur district like Phulwari Wildlife Sanctuary, where it is seen commonly growing near Katawali Jer in Daiya Forest Block. H. furcifera is common in the forests of Nala village in Phalasia Range; Sera, Jhameri and Nalsandol blocks of Jhadol Range and Ubeshwar Block of Girwa Range. $H$. furcifera is the most common terrestrial orchid in southern Rajasthan found extensively in forest areas. In Nala village it commonly grows during rainy season below Madhuca indica trees in maize fields.

In Ubeshwar Block of Girwa Range, $H$. plantaginea is seen growing with $H$. furcifera along a seasonal nallah under the dense thicket of Lantana camara. H. plantaginea is a tuberous herbaceous terrestrial orchid with prostrate leaves on the ground. Its scape is a many-flowered raceme with flowers of milky white colour. Flowers of this species have trilobed lips. Their spurs are long and slender, larger than the ovary. It flowers at the end of the monsoon. This species is seen on the way from Ubheshwar to Dodawali under dense forest cover

\section{REFERENCES}

Mehta, M.R. (1979). Flora of Mount Abu. Ph.D. Thesis. University of Jodhpur. Sharma, S.K. (2001). New records of Nervilia aragoana in Rajasthan. Journal of the Bombay Natural History Society 98(3): 493.

Sharma, S.K. (2002). Occurrence of Habenaria longicorniculata Grah. Family Orchidaceae in Mount Abu Wildlife Sanctuary, Rajasthan. Journal of the Bombay Natural History Society 99(1): 156.

Sharma, S.K. (2003). Orchid Flora of Phulwari Wildlife Sanctuary, Udaipur district, Rajasthan. Zoos' Print Journal 18(10): 1227-1228.

Shekhawat, R.S. (2003). Sitamata Wildlife Sanctuary Management Plan (for period 2003-04 to 2012-13). Department of Forests, Rajasthan.

\section{ACKNOWLEDGEMENTS}

The author is very grateful to Sh. R.G. Soni, Sh. R.P. Kapoor, Sh. U.M. Sahai, Sh. Arun Sen, Sh. Jagdeesh Rao, Dr. S.S. Katewa and Dr. Chhaya Bhatnagar for facilities and encouragements.

Table 1. A list of orchids seen from 1993 to 2003 in Sitamata Sanctuary

\begin{tabular}{|c|c|c|c|}
\hline Type of orchid & Name of species & Most preferred habitat & Localities where recorded (with local status*) \\
\hline Epiphytic & $\begin{array}{l}\text { Vanda tessellata (Roxb.) } \\
\text { Hook. ex G. Don } \\
\text { Acampe praemorsa } \\
\text { (Roxb.) Blatt \& McC. }\end{array}$ & $\begin{array}{l}\text { Rough barked stem and branches of tree species like } \\
\text { Madhuca indica, Bridelia retusa and Buchanania lanzan } \\
\text { Rough barked stem and branches of Madhuca indica }\end{array}$ & $\begin{array}{l}\text { Valmiki Ashram (C), on the way to Sitamata Temple } \\
\text { (C), Jakham Dam Road (C) } \\
\text { Valmiki Ashram (C) }\end{array}$ \\
\hline \multirow[t]{2}{*}{ Terrestrial } & $\begin{array}{l}\text { Eulophia ochreata Lindl. } \\
\text { Nervilia aragoana Gaud. }\end{array}$ & $\begin{array}{l}\text { Cool, moist and very shady stream banks } \\
\text { Moist banks of streams and ground floor under } \\
\text { dense trees rich in humus and litter. }\end{array}$ & $\begin{array}{l}\text { Valmiki Ashram }(C) \text {, Bhagi Baori }(R) \\
\text { Bank of Sitamata river on the way to Sitamata } \\
\text { temple }(R)\end{array}$ \\
\hline & Habenaria furcifera Lindl. & $\begin{array}{l}\text { Moist and shady areas under Mahuwa (Madhuca } \\
\text { indica) trees }\end{array}$ & Valmiki Ashram \\
\hline
\end{tabular}

* C - Common; R - Rare 